\title{
Postmodernity Society and Education in Philosophy and Humanities
}

\author{
Irina Ponizovkina \\ Department of History and Philosophy \\ Plekhanov Russian University of Economics \\ Moscow, Russia \\ Email: irina-ponizovkin@mail.ru
}

\author{
Elena Agibalova \\ Department of Foreign Languages \\ Plekhanov Russian University of Economics \\ Moscow, Russia \\ E-mail: elenagib@rambler.ru
}

\begin{abstract}
The paper presents relevant problems in teaching the humanities. Special attention is paid to the analysis of impact that modern social development trends have on philosophic education in Russia. The authors of the paper rely on the conclusions based on definite facts and offer their own answers to the principal questions relevant to education today.
\end{abstract}

Keywords—postmodernity society; contemporary education; philosophic education; information society; scientometrics; knowledge society; all humanities training

\section{INTRODUCTION}

Human society that is developing today in the course of the information revolution is often dubbed "knowledge society". But to what extent does this notion reflect the essence of the existing human era? Given that postmodernity atmosphere that is now dominating the society is actively invading all the processes in spiritual, political, ideological and educational spheres. A philosophical analysis and understanding of the social essence peculiar to postmodernism specific features explain a lot of social phenomena in spiritual, economic and educational spheres. The last one is especially worth exploring in more detail as postmodernity spirit and the latest mental aspirations influence directly the development and status of philosophy being a special area of knowledge and educational discipline.

Today, human society has entered the stage of major changes that is characterized by specific features which are not always visible to a common person but are interesting for scholars. Postmodernity notion was intensively developed in social and humanitarian sciences and obtained its theoretical status in the 80-s of the past century in the works on J.F.Lyotard [1] [2]. The works of such philosophers as J.Baudrillard, G.Deleuze, J.Derrida and others made this notion generally recognized and outlined the major opportunities for its main research perspectives [3].

\section{SPECIFIC FEATURES OF POSTMODERNITY ATMOSPHERE}

Modern society with its eclecticism, the perception of the world as uncertainty and certain chaos, absolutization of everything relative and focus on consumerism develops new axiological attitudes in society. It is expressed through declaring relativity of any values even those that have been established for centuries. This moral relativism is especially traceable and popular among young people. Even eternal values like love, the good, loyalty, sacrifice, duty, honesty, hard work are questioned and reviewed in the context of new trends and paradigms of public conscience. Universal modernity principles that constitute a clear hierarchical vertical of social relations and values, a sustainable model of a social system are substituted with a diversity of new focuses, expectations and processes in different social functioning spheres.

Contemporary philosophers and social scientists while carefully studying the overwhelming dynamics of the surrounding reality are trying to track and explain general trends and development perspectives. The researcher $\mathrm{Z}$. Bauman revealed the main specific feature of postmodernity era and called it instable-fragmental liquid modernity. He is supported by F. Emery who compares dynamic processes in a society with the movement of soil under your feet. That is why this is for a reason that A. Giddens sees the reality as constantly "escaping" and causing a sensation of unpredictability, inability to grasp the essence [4]. And P. Vaill compares it to permanently boiling water when you have a feeling of constant change and disorder [5]. This is all aggravated by the information revolution.

Such manifestations of postmodernity in a society have a significant impact on the educational process at universities and on the role of the humanities, especially philosophy, in them. This is a real challenge to contemporary education.

However, other modern trends that complicate the social reality pattern and require the resolution of controversies arising between them, also need to be considered.

Postmodernity trends in the development of public conscious are accompanied by such phenomena in the spiritual, economic and political spheres as globalization, development of the information society and knowledge society. At the same time, these phenomena are linked by quiet ambiguous relations. Sometimes the notions of the information society and knowledge society are seen as synonyms, however, apart from being non-identical, they also contradict each other a lot in terms of their practical 
functioning. The only sure thing is that they influence all together the Russian educational space.

\section{TRANSFORMATION OF RUSSIAN EDUCATIONAL SPACE MEANINGS IN THE 21ST CENTURY}

Commitment to globalization in the educational sphere resulted in integration of the Russian educational sphere into the Bologna Process with the aim of approaching different national educational systems and unification of educational standards. In fact, the Bologna System reflects the existing trends: on the one hand, globalization requires more and more unification and, thus, a more in-depth technologization of education and, on the other hand, this is a certain way to overcome the dominating spur of the moment, "fluidity" and "elusiveness" of postmodernity, an attempt to squeeze a dynamic academic activity in a certain framework of qualifications and single standards. Moreover, it complies quite well with aspirations of a consumer society. Focus on consumers and comprehensive commoditization are dominating more and more in the development of contemporary education. Transferred knowledge becomes a commodity and the educational system develops into educational services with a document flow accompanying it. Teaching scholars start fulfilling functions of experts whose activity should be subject to comprehensive formalization and standardization. Senior executives should acquire qualities of efficient managers.

Mastering of, first of all, professional competences is becoming the main quality parameter of education. Quality control parameters are strictly regulated and are set through different types of tests, written exams, etc. It may be quite acceptable and even efficient for certain disciplines. However, for philosophy tests and written exams can serve just as a secondary complementary tool as external strict formalization dilutes the very essence of philosophy and rhetorical exercises. Philosophy is not a set of facts and ready-made knowledge but rather a capability to engage in a dialogue, an ability to formulate and defend particular views in certain key sense-making issues based on learnt notions, facts and knowledge about the history of philosophy. Philosophy has developed and existed as a dialogue of world-views. This is what constitutes its uniqueness and educational-pedagogical potential as an academic discipline. Higher education is a chance to get in touch with supreme values (culture, cognition, etc.) and their implementation in professional activity. This is only possible through education in the humanities and philosophy.

One should pay attention to the respected opinion of Peter Veill, a famous expert in Management, who said, "With the growth of the service industry, it becomes more and more evident that we shouldn't treat services using the same criteria as the criteria for production. Services can't be "packed" into a standard package. The service is made up of human interaction and lasts throughout time...It demands much efforts to give up the familiar scheme of "product units" [6].

These words should be kept in mind while assessing the work of the academic community that has been surprisingly fitted today into the service industry. Qualities of an instructor-Personality and the status of a Scholar have now been reduced to the status of a controlling expert and a unit of scientific-spiritual production whose "trade" is also subject to strict control and standards - by the quantity and type of publications, the Hirsch index, the grants received, certain ratings, etc. Scientometrics comes to the forefront and starts being a bigger concern for the academic community.

The famous scholar and member of the Academy of Sciences V. Stepin while speaking on November 30, 2015 at a video conference entitled "Is scientometrics efficient?" at the Faculty of Philosophy at Moscow State University also expressed his concern [7]: doesn't scientometrics represent an obstacle on the way of the technological revolution, of those humanities scholars who create radically new theories and paradigms and can't at first count on citations? What do we do with scholars who spent years writing fundamental works? Scientometrics requires fast return fixed in quarter reports. What about the result? An endless flow of lowquality "academic" literature, hastily drafted articles, making money off these publications in magazines and the reduction of their trustworthiness, manipulations with the Hirsch index, time wasted by a scholar. Substantial rather than formal means should be used to find ways to overcome postmodernity relativism and uncertainty in education.

It is relevant not only in Russia. Such "imitation of science" characteristic to postmodernity overwhelmed the whole world. Scholars ring the alarm. Physicist D. Davidovich, professor at the University of Belgrade (Serbia), member of the Vinca Institute of Nuclear Sciences expressed his radically negative attitude towards methods of contemporary scientometrics: "scientometric technology leads to completely negative selection for science" especially in small counties (like Serbia) or those that lost their sovereignty or those not included in the network of "insiders" [8]. Academic staff of such countries are moved forever and very often artificially to the fringes of pseudoscientific community as criteria for numerous ratings and publications are usually drafted considering your own interests. The Scientific Council that was held in Moscow on January 21, 2016 also discussed the same issue controversy and insufficient neutrality of foreign ratings. According to Russian scientists, the country needs to create its own assessment criteria in terms of scientific achievements and knowledge. Russian President V. Putin supported this idea: "As for the assessment criteria - of course, they need to be improved...Until we have our own criteria, we will have to be guided by what we have and what we are offered" [9].

During the latest World Congress of Philosophy held in Athens in 2013 and entitled "Philosophy as inquiry and way of life", while in Russia the grant movement was actively gaining momentum and popularity as a performance indicator for scholars, foreign delegates expressed a concern about the downside of grants especially in a socialhumanitarian sphere. Chasing grants of multinational corporations and different foundations with rather vague statutory aims and objectives doesn't contribute to 
transparent experiments and impartial research [http://www.sim.kz/interviews/view/29743]. In the European scientific community today, grantwriting is often qualified as a malady of the western science that requires scientists' efforts and wastes funds not always contributing to the search of the truth. Professor Jan Blommaert in his article "Rationalizing the unreasonable: there are no good academics in the EU" [10] says that grant writing results in heteronomy (a term introduced by I. Kant) - actually, formal subordination of research and innovative projects to nonacademic criteria, useless "hustle for competitiveness". In Russia, the downside of grants together with their pitfalls connected with the current political situation haven't been fully perceived and comprehended yet. In this case, one should not be surprised that the scientific analysis is substituted with social pseudoscientific myths, ideological assessments and clichés.

\section{ROLE OF PHILOSOPHIC EDUCATION}

The creation of the information society and postmodernity trends accelerate each other in the development of contemporary mosaic "split" conscious that fully demonstrates its dominance in the educational sphere [11] [12]. Principles of scientific rationality and deterministic vision of the surrounding reality are substituted with skepticism regarding the ability to experience social life and a human as closed functional systems. Deconstruction that is characteristic for postmodernity destroys beliefs about the dedicated cognitive process that grasps the essence and laws of all that's happening around. Developed multimedia technology (TV, Internet, advertising, etc.) with a kaleidoscope of news, random facts, imposition of diverse controversial meanings, flashing storylines and focus on success result in abandoning the search of a vector in the development of public processes and its substitution with technologization of approaches.

General humanitarian-philosophic disciplines give way to brief and often applied courses in a very specific field that are growing in number. A mosaics of randomly formed disciplines develops and successfully fits into the general atmosphere of utilitarianism. Commoditization of professional training results in the reduction of all humanities component or even eliminate it as excessive load which raises the price of educational programs. Over the last decades, the amount of philosophy class hours decreased sharply which is a result of the above-mentioned processes and misunderstanding of consequences of such wrong policy.

However, the consequences are already evident. A student develops a mindset that abandons any attempts to clearly systemize knowledge about the world, doesn't operate basic notions (the good - the evil, freedom necessity, systematicity, fact, etc.) and erases the demarcation line between scientific and ordinary cognition. Many students today don't feel the need to turn to the accurate meaning of fundamental notions and interpret their meaning freely often confusing notions - "matter" with "thing", "self-respect" with "self-love", "egoism" with "individualism". They even bring it to the level of a principle: everyone has their own opinion. However, it quite corresponds to the general inclination of postmodernity conscious to individualization, absolute freedom of thought and liberation from traditions and norms. Students find tasks that require the construction of schemes most difficult. The results of such work demonstrate that students do not navigate well in the hierarchy of categories, can't structure levels and identify the nature of interconnections between the elements. Very often such scheme-building tasks are substituted with a text which reveals problems in systematization of material as well as the low level of conceptual thinking.

This trend has been fixed also as a result of special studies (for example, by L. Vekker, G. Crabtree from Stanford University) demonstrating the decrease in the human intelligence level. Head of the Social Psychology laboratory at Saint-Petersburg State University, Head of Diagnostics and Development of Capabilities Center L. Yasuykova based on the results of monitoring school and university students' intellectual development made a conclusion that less than $20 \%$ of people have comprehensive conceptual thinking [13]. Announcements of expensive trainings in the development of conceptual thinking for businessmen and top-managers have already appeared. 30-40 years ago, basics of such thinking were established already in school and at university they were completed.

Then, a question common for all Russian, arises: what do we do? Should we put up with such trends? Should we take it for granted not considering postmodernity trends? Should we wait for the better times? However, it doesn't match the initial attitude of developing "knowledge society": knowledge is authority. Or the one by Bacon: knowledge is power. Power or authority (over circumstances, phenomena, nature, etc.) can be gained only through a truly deep knowledge and not imitation of knowledge. Decisions made on the basis of superficial knowledge at the preconceptual stage of interpretation of the surrounding events are impossible to implement. And in modern conditions of a constantly changing world, unstable social systems, cataclysms the risk of catastrophic consequences of wrong subjective decisions is too high.

\section{CONCLUSION}

The future of Russia and civilization depends on which trend wins: education as a business project or education as a form of multi-faceted socialization (including in the professional sphere) of a potential expert. The second approach suggests an increase in the role of philosophy in the educational process. Philosophy in the educational process serves not only to demonstrate and explain modern trends and their potential negative consequences but also help overcome them. The study of philosophy and philosophic disciplines is able to systematize accumulated knowledge about the world and thus overcome fragmentation of cultural-educational space, combine together jigsaw puzzles of numerous academic programs. In the process of study, philosophic disciplines will help release students from the triviality of imaginary creativity, dilettantism and methodological unawareness, understand the genuine beauty of thought and the search of the truth. This approach is 
reflected in the Federal Law of the Russian Federation on Education that interprets education as "a single dedicated process of education and training which is a worthwhile cause and is implemented for the benefit of a human, family, society and state..."[14]. This approach that is traditional for Russian education has not yet been tested.

Modern society is following a thorny path to understand the importance of philosophic education. And, may be, the Russian society will have to pay an extremely high price for undue understanding of this necessity amid complicating information environment and the developing "knowledge society".

\section{REFERENCES}

[1] J.-F. Lyotard, La Condition Postmoderne: Rapport sur le Savoir. Paris: Éditions de Minuit, 1979; The Postmodern Condition: A Report on Knowledge. Trans. Geoffrey Bennington and Brian Massumi. Minneapolis: University of Minnesota Press, 1984.

[2] J.-F. Lyotard, The Postmodern Explained: Correspondence, 19821985. Ed. Julian Pefanis and Morgan Thomas. Trans. Don Barry. Minneapolis: University of Minnesota Press, 1993.

[3] B. Duignan, "postmodernism (philosophy) (Encyclopædia Britannica)". Encyclopædia Britannica. Retrieved 10 April 2018.

[4] A. Giddens, "Runaway World: How Globalization Is Reshaping Our Lives", Moscow: "The whole world", 2004, 120 p.

[5] P. Vaill, "Managing as a Performing Art: New Ideas for a World of Chaotic Change", Wiley, 1991, 264 p.

[6] Ibid., p. 27.

[7] V. Stepin, Is scientometrics efficient?, https://vk.com/wall107015054?offset=20\&w=wall-107015054_14\%2Fall [accessed date: 15.04.2018]

[8] D. Davidovich, The social status of a scientist and scientometrics, https://vk.com/wall-107015054?offset=20\&w=wall107015054_12\%2Fall [accessed date: 15.04.2018]

[9] The Development of Science, the Preservation of Material Resources and Other Topics - at the Presidential Council in the Kremlin", http://www.1tv.ru/news/social/300438 [accessed date: 15.04.2018]

[10] J. Blommaert, Rationalizing the unreasonable: there are no good academics in the EU, http://alternative-democracyresearch.org/2015/06/10/rationalizing-the-unreasonable-there-are-nogood-academics-in-the-eu/ [accessed date: 15.04.2018]

[11] O.V. Chistyakova, Humanitarian-anthropological aspects of contemporary education (philosophical analysis) // Proceedings of the 3rd International Conference on Arts, Design and Contemporary Education (ICADCE 2017). Vol. 144. Moscow, Russia. May 29-30, 2017. Paris: Atlantis Press, 2017, pp. 610 - 613.

[12] O.V. Chistyakova, On the possibility of a synthesis of secular and religious values in the context of modern humanitarian knowledge // Proceedings of the 2017 4rd International Conference on Education, Language, Art and Inter-Cultural Communication. (ICELAIC 2017). Advances in Social Science, Education and Humanities Research, Volume 142. Moscow, Russia, October 17-18, 2017. Paris: Atlantis Press, 2017, pp. 750 - 754.

[13] The Gap Between Smart and Silly Increases. Interview of L. Yasukova to $\quad$ Rosbalt. 4.12 .2013 , http://www.rosbalt.ru/main/2013/12/04/1207437.html [accessed date: 29.04.2017]

[14] Federal Law 29.12.2012 N 273-Ф3 “On Education of the Russian Federation", 2012. Collection of legislation of the Russian Federation. Issue No. 53, 7598. 